\title{
A SYSTEM OF HANDLING AND DEPOSITING PERSONAL ARCHIVES
}

\author{
By Ellen D. Spaulding
}

In the summer of 1920 began our survey of manuscript collections in other institutions. Our present system of handling and preserving private papers resulted.

At the New Hampshire Historical Society, Concord, Otis Hammond, curator, the manuseripts were kept in a large combination locked vault. Many were bound in fine bindings, and others were kept in steel vertical filing cases. All envelopes and unimportant letters and papers were discarded.

Julius Herbert Tuttle of the Massachusetts Historical Society, Boston, curator in charge of their numerous and interesting collections, exhibited many manuscripts in cloth binding, others ready to be bound, and contained in folders resembling legal folders, but made dust proof by use of overlapping ends. Each volume or package was marked with the name of the collection and the catalog number, indicating the decade and year in which it belonged. All materials were chronologically arranged.

The New York Historical Society, New York City, had its materials chronologically arranged in pamphlet boxes, and cataloged.

In 1921 the final consignment of the great collection from General Grenville M. Dodge ${ }^{1}$ was received. Immediate and incessant requests for materials bearing on the value of railroad properties made by the railroad companies for their use in meet-

1Grenville Mellen Dotlge was born in Danvers, Massachusetts, April 12, 1831. and died in Council Blufis, Iowa, January 3,1916 . He was graduated from the Military University at Norwich. Vermont, in 1850 as a civil engineer. The next year he began work as a civil engineer for the Illinois Central Roilroad and during the few following years was in that capacity with the Chicago, Rock Island and Pacfic Railway through Iowa and with the Pacific Railway system through Nebraska. In 1861 he raised the Fourth Iowa Infantry and entered the war as its colonel. He served under Fremont and Curt is in Missouri, under Grant at Vicksburg, under Sherman at Atlanta, and as a major general suc: ceeded Rosecrans as commander of the Department of Missouri. In 1866 he resigned from the Army and was appointed chief engineer of the Union Pacific Railroad, the first trans-continental road, and is regarded as its builder. He led in the construction of many other railroads in the Southwest. He served one term in Congress, 1867-69, and declined further service, was a delegate to the Republican national conventions of 1868 and 1876 . Was p resident of the Society of the Army of the Tennessee, was commander-in-chief of the Mil tary Order of the Loyal Legion, and received numerous other military and civil honors. 
ing the requirements of the Interstate Commerce Commission and by other investigators demanded immediate handling. We quickly arranged the collection by classifying the materials of each specific railroad or project under subject heads and in chronological order. Those subject headings were as follows:

Agreements and Contracts

Articles of Incorporation

Correspondence

Estimates

Instructions

Maps and Profiles

Miscellany

Pamphlets

Receipts and Vouchers

Reports

Statements (trial balances, monthly statements, etc.)

Subsidiary Roads and Corporations

After the Dodge emergency situation passed, and in the year 1922 , a further and general study was made of the care of manuseripts. The Library of Congress, through J. C. Fitzpatrick, assistant librarian of the manuscript division, advised: "Chronological arrangement of papers, wherever possible, is the arrangement which most successfully meets the needs of the greater number of investigators. Strict chronology is not, however, an ironclad rule, and in the case of the Dodge papers as described it seems probable that it can be modified to some extent." At the same time Mr. Fitzpatrick sent his brochure Notes on the Care, Cataloging, Calendaring and Arranging of Manuscripts, which has been constantly studied and in a great measure followed throughout the development of our principles of arrangement and classification of private papers.

Where a collection of ordinary letters has been accompanied by masses of receipted bills, canceled checks, newspaper clippings and the like, separate classification has been made, but classified and arranged chronologically so as to parallel the principal collection, regarding the fact that the identity of enclosures with the principal missives must always be retained. We have separated them only when the over-bulk of the less 
consequential materials has embarrassed the file from the physical difficulty of incorporating it. In its final arrangement the Dodge materials are classified as follows:

Civil War Materials

Commissions

Correspondence

Diaries

Finance

Law

Letter Books

G. A. R.

Manuseripts

Maps and Profiles

Newspaper Clippings

Pamphlets

Pictures

Railroads

Searcely less important to us than the settling upon the prineiples of classifying and handling materials was that of settling upon the type of receptacles in which to finally deposit them.

We found containers differed in the offices and vaults of lawyers and other professional men, railroad and other quasi public officials and of public officers. Those for different years often differed in the same depository as widely as other furniture and facilities and as widely as in different offices. The best one can make of it is that the method in use and the styles of devices have throughout prior years been the suggestions of stationery salesmen and "systems" recommended by experts. In repositories of institutions resembling ours there was also variety, but in every instance a higher efficiency and greater simplicity than is to be found in the ordinary current business or even archives sections of the offices and institutions above referred to.

Miss Sally Shaw of the Massachusetts Historical Society used the case we show as illustration No. 1. Doctor Albert Bushnell Hart of Harvard University used manila folders, with colored tabs so attached as to reveal at a glance his classification. He employed no boxes or containers which might be likened to bound volumes we think preferable for housing and for ready library 
administration. Mr. William Coolidge Lane, librarian of the Widener Library, Cambridge (the manuscript division at Harvard College), took us through that fine collecton of manuscript materials, the substance and variety of which seem unequaled,

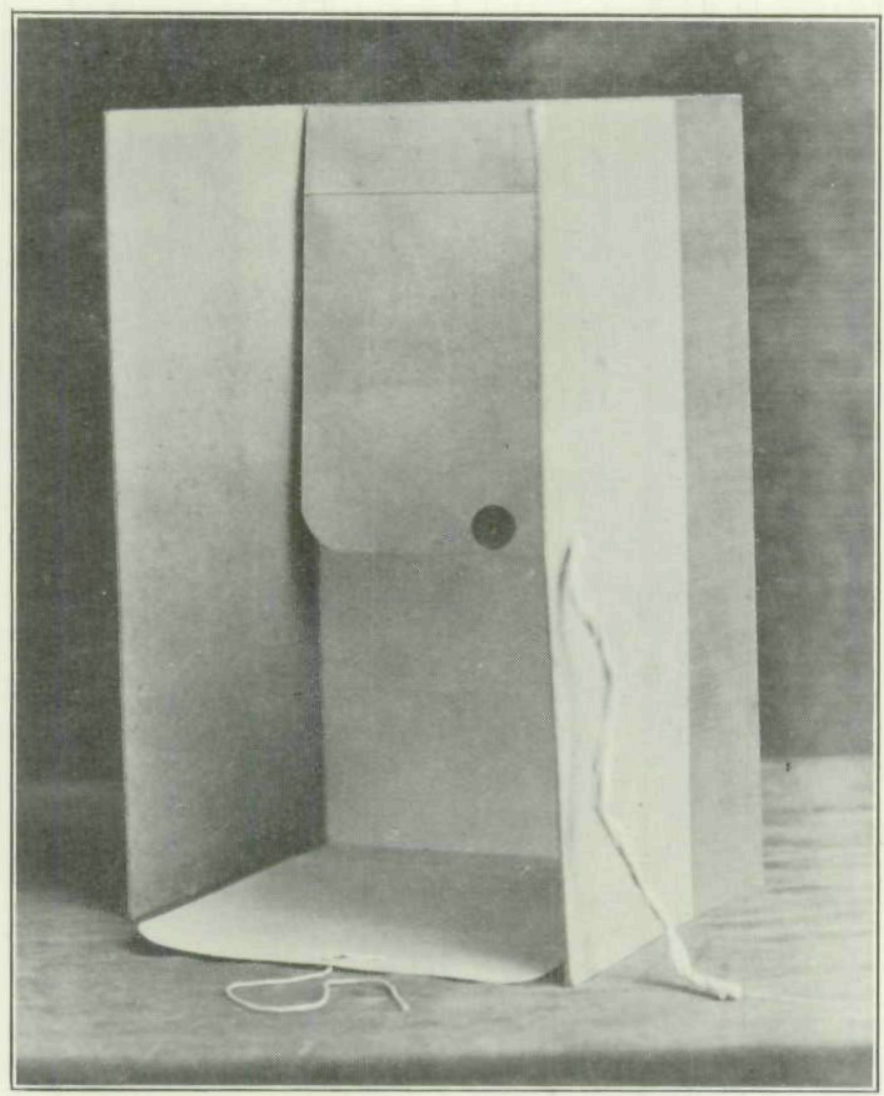

No. 1.

but the containers were not uniform, and await some such solution as we are endeavoring to arrive at in the present study.

Mr. Victor H. Palsits of the New York Public Library, a pioneer in better handling and housing of public archives, exhibited a box identical with the one we use in our division of 


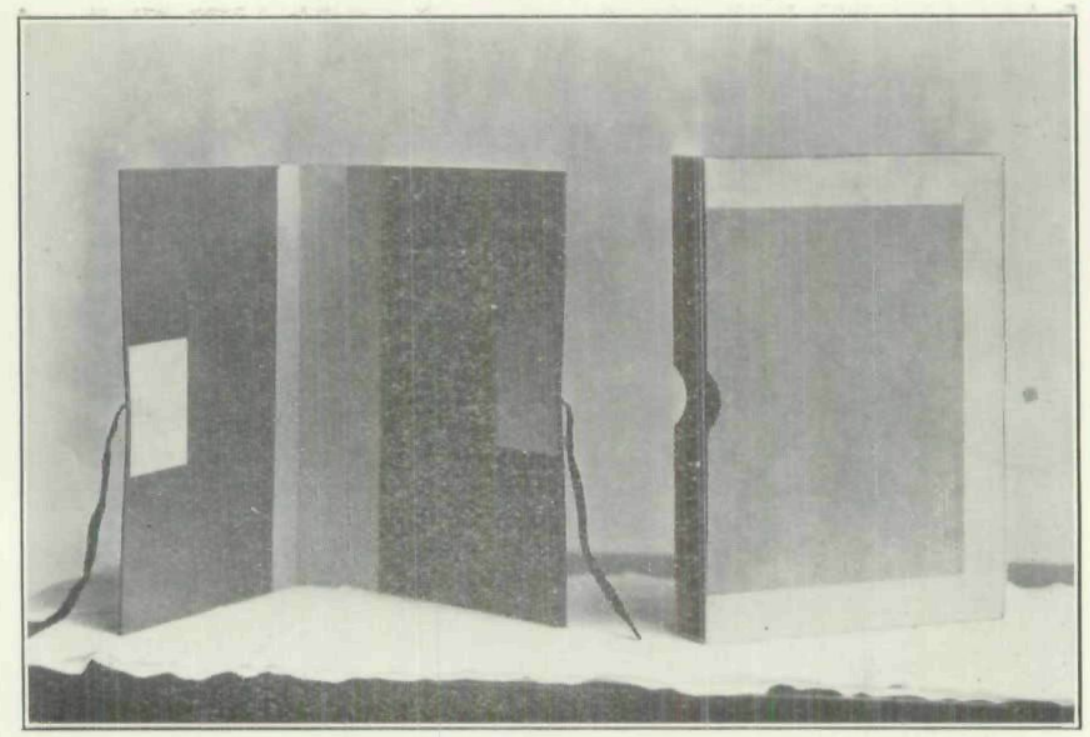

No, 2.

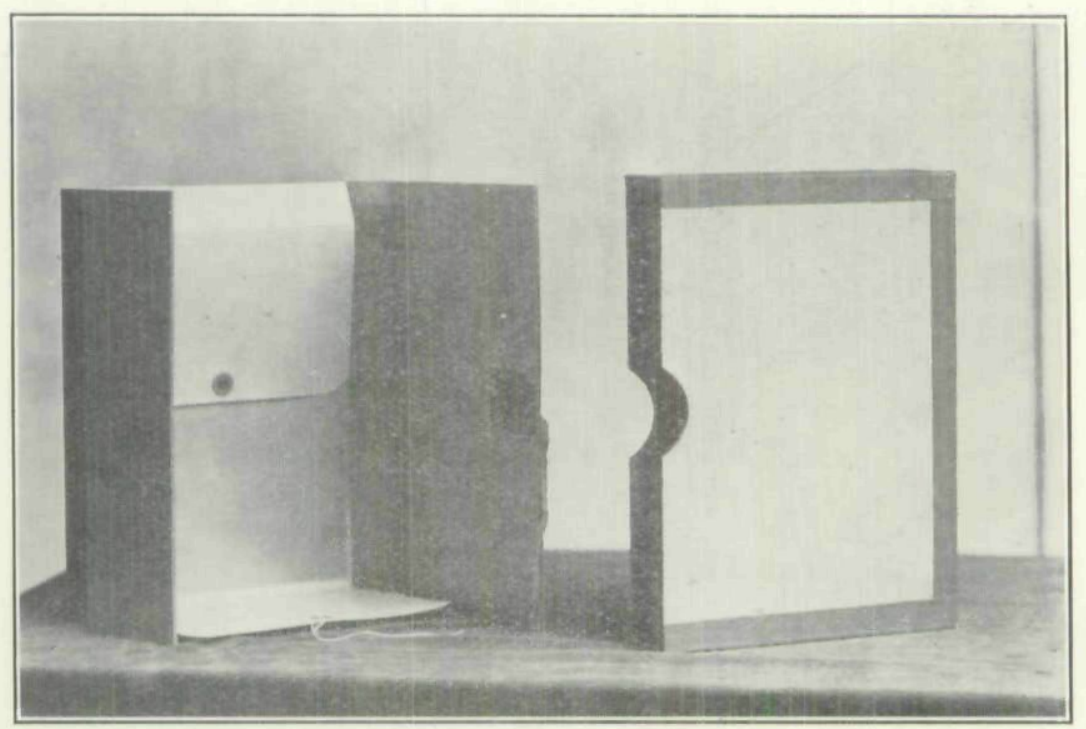

No. 3 . 
public archives, illustrated on page 251, Vol. XVI, Third Series, Annals of Iowa.

We found in the library of congress (and borrowed from $\mathrm{Mr}$. Fitzpatrick) one of the cases used by them for many of their unbound collections, and which we show in our illustration No. 2. It was from the first and last named cases that we evolved one which for our purposes seems better adapted than any other of which we know. Illustration No. 3 will better explain than will our description. However, the case is made from heavy binder's board, covered with blue vellum, each back-stamped in gilt letters with the name of the general collection, the inclusive years and the volume number. It may be objected that the inclusive dates on each volume should be back-stamped. That could be true only where a collection is beyond the possibility of growth. We find that collections of those dead forty years which reached us twenty years ago are frequently augmented within the current year by scores of missives varying in dates through a range of twenty-five years.

Our container is preferred for its resemblance to those after which it was patterned and for the combination of those factors into one structure, then with the addition of the button and tie, which hold the flaps more nearly dust proof than any we examined. This is a mere combination in this respect of details of the Library of Congress and the Massachusetts Historical Society containers, to which we added the button and tie.

With this container or folder slipped into the jacket backstamped as above described, our collection is amenable to all the rules of library classification and administration. It is dust proof, is readily identified on request, and favors avoidance of confusion through careless handling and displaying. Our next step will be to eatalog according to standard library methods.

Collections we have received during recent years will all be handled and deposited upon the above system. They will be calendared according to the Library of Congress methods. This has been done in the instance of the papers of Alonzo Abernethy, ${ }^{2}$

2Alonzo Abernethy was born in Sandusky, Ohio, April 14. 1836, and died in Tampa, Florida, February 21, 1915. In 1854 he removed to Fayette County. Iowa, taught school, and attended Burlington Academy and Chicago University. In 1861 he enlisted as first sergeant in Company F. Ninth Iowa Infantry, and by the end of the war rose to the rank of lieutenant colonel. He was a member of the General Assembly in 1866. In 1870 he became principal of the Univer- 
Charles Mason, ${ }^{3}$ Emerson Hough ${ }^{4}$ and William H. Fleming. ${ }^{5}$

We venture, in example, to append the Charles Mason calendar in excerpt, which indicates not only the system, but the importance of the collection.

1854

May 15

1861

Sept. 23
GRIMES, JAMES W. [Burlington] To Charles Mason [Washington]. Re calumnious article against Grimes in Burlington Mirror. Asks Mason if Alex Stephens stated in his hearing that Iowa would be a slave state in fifteen years. A. L. S.

MORSE, SAMUEL F. B. [Poughkeepsie] To Charles Mason [Washington]. Pleased with Mason's letter accepting nomination, but thinks his views too broad, unselfish and patriotic to be popular. Describes "Secession" and "Abolitionism." Thinks England back of much trouble. Believes most people desire peace. Is trying to put his ideas in print. A. L. S.

sity of Des Moines, was state superintendent of public instruction from 1872 to 1876, followed that service by being president of Chicago University for two years, and was president of Cedar Valley Seminary, Osage, from 1881 to 1902. He was a member of the Board of Regents of the State University of Iowa from 1890 to 1909 and was the author of many edueational and historical articles in yarious publications.

Charles Mason was born in Onondaga County, New York, October 24, 1804. and died near Burlington, Iowa. February 25, 1882 . In 1829 he was graduated from West Point Military Academy at the head of his class. He studied law and practiced a short time in New York City, was employed as a writer on the New York Evening Post, but in 1837 was appointed a United States district attorney of Wisconsin Territory and removed to Burington. In 1838 when Iowa beeame a territory he was apponted chief justice of Iowa Territory, which position he held until the territory became a state in 1846. He was one of the commission which revised the laws and prepared the Code of 1851 . From 1853 to 1857 he was United States commissioner of patents and resided in Washington, but returned to Burlington at the end of that service. In 1858 he was a member of the first State Board of Edueation. In 1861 he was nominated by the Democrats for governor, but declined. In 1867 he was again nominated for governo:, but was defeated by Samuel Merrill. He was a delegate to the Demoeratic national conventions of 1868 and 1872 .

¿Emerson Hough was born in Newton. Iowa, June 28, 1857, and died in Chicago, Illinois, April 30, 1923. He was graduated from the Newton High School, and from the State University of Iowa in 1880. He began the practice of law in New Mexico, but soon began writing sketches which were published principally by the American Field and Forest and Stream. In 1889 he removed to Chicago and took over the office there of Forest and Stream. In 1902 he wrote The Mississippi Bubble, which was his first really successful novel. During the next twenty years he produced The Story of the Couboy. The Girl of the Halfway House, The Way of the West, The Story of the Outlas, Fifty-four Forty or Fight, Young Alaskans in the Far North, The Sage-brusher and many other stories, and in 1922 he wrote The Covered Wagon, wh ch achieved a great success.

5 William Henry Fleming was born in New York City Apill 14, 1833, and died in Des Moines, Iowa. October 14. 1923. In 1847 he began as an apprentice in the printing trade in the office of the Christian Intelligencer in New York City. In 1854 he removed to Davenport, Iowa, and for several years worked on papers there, principally the Davenport Gazette, being city editor of it. Some time during the Civil War he was employed by Adjutant General Baker in his office in Cinton. He removed to Des Moines in 1867 and became deputy secretary of state under Ed Wright, but resigned in 1869 to become private secretary to Governor Merrill. He acted in thet eapacity not only for Merrill but for Governors Kirkwood, Newbold, Gear. Drake and Shaw. At intervals he was deputy state auditor, did much other special work about the State House, and did newspaper and historical writing. From 1902 to 1907 he was in a position in the United States Treasury Department under Secretary Shaw. 
Copyright of Annals of Iowa is the property of State of Iowa, by \& through the State Historical Society of Iowa and its content may not be copied or emailed to multiple sites or posted to a listserv without the copyright holder's express written permission. However, users may print, download, or email articles for individual use. 